\title{
MASYARAKAT DAN KEBUDAYAAN TERNATE DALAM PERSPEKTIF SEJARAH
}

\author{
Rustam Hasim \\ Staf Pengajar Program Studi Pendidikan Pancasila dan Kewarganegaraan, FKIP-UNKHAIR
}

Email: rustamhasyim@gmail.com

$\begin{array}{ll}\text { Diterima } & : 08-09-2019 \\ \text { Direvisi } & : 15-10-2019 \\ \text { Dipublikasi } & : 04-11-2019\end{array}$

Abstrak. Tulisan ini menjelaskan kehidupan masyarakat Ternate dalam dimensi sejarah. Kesultanan Ternate berdiri pada tahun 1257 M dengan raja (kolano) pertama bernama Baab Mansur Malamo. Masyarakat Ternate mendiami daerah kepulauan Ternate secara turun temurun masih setia melaksanakan adat istiadat kesultanan Ternate yang telah diwariskan oleh leluhurnya. Masyarakat Ternate tumbuh dan berkembang dengan segala keragaman budayanya. Berdasarkan catatan di daerah Ternate terdapat 12 sub etnis (suku) dengan 13 bahasa lokal. Corak kehidupan sosial budaya masyarakat di Ternate kental dengan budaya Islam yang dianut oleh Kesultanan Ternate. Marimoi Ngone Futuru Masidika Ngone Foruru adalah ajakan kearah solidaritas dan persaudaraan antar etnis di Ternate. Potensi budaya ini merupakan modal pembangunan yang paling berharga untuk dikembangkan.

Kata Kunci: Masyarakat, Kebudayaan, Sejarah dan Pulau Ternate.

\section{PENDAHULUAN}

Ternate mengemuka dalam catatan sejarah terutama karena hasil rempah-rempahnya. Tanahnya yang subur menjadikan Ternate penghasil cengkeh dan pala terpenting di Kepulauan Maluku. Keadaan itu didukung oleh posisi geografisnya yang terletak dalam kesatuan lintasan Laut Maluku, Sulawesi, dan Laut Sulu yang merupakan satu kesatuan, sehingga menempatkan kawasan ini sebagai bagian dari jalur utama internasional. Menurut Leonard Y. Andaya, perdagangan rempah-rempah di Ternate menjadi penggerak aktivitas perniagaan di kawasan Asia Tenggara dan memunculkan interaksi dengan berbagai bangsa dan budaya di Nusantara (Leonard Y. Andaya, 1973).

Sebagai pusat kegiatan ekonomi dan perdagangan, hubungan komunikasi diletakkan jauh ke luar batasbatas Nusantara. Akibat hubungan-hubungan itu, terjadi konvergensi dan tercipta kondisi sosial budaya termasuk sosiolinguistik yang memungkinkan berkembangnnya segala unsur kebudayaan. Leirissa mengungkapkan bahwa penduduk Maluku (Ternate) terdiri dari berbagai suku bangsa di Nusantara yang bermigrasi ke pulau ini sejak masa kolonial. Bahkan bila dikaji lebih jauh ke belakang, sejak masa emporium dan imperium, telah banyak suku bangsa dan ras dari berbagai negeri maupun benua datang ke Ternate (R.Z. Leirissa,1999).

Pertemuan antar-ras dan suku bangsa ini menimbulkan percampuran, sehingga melahirkan keturunanketurunan yang baru dengan berbagai pola tingkah budayanya. Maka tidak mengherankan jika penduduk Ternate saat ini memiliki beragam bahasa dan tradisi yang sama atau berbeda dalam satu lingkungan tertentu, namun tetap memperlihatkan ciri kebudayaannya masing-masing. Interaksi perdagangan rempahrempah yang intensif dengan kelompok suku bangsa itulah yang memungkinkan terbentuknya organisasi atau pemerintahan awal di Pulau Ternate.

Melihat berbagai kondisi dan latar belakang kehidupan yang terdapat di dalamnya, menjadi penting dikedepankan untuk mendapatkan informasi atau gambaran utuh tentang dinamika internal masyarakat Ternate yang telah terpola dan mengakar dalam proses historis yang panjang (Kuntowijoyo, 2002). Oleh 
karena itu, pokok bahasan ini akan diawali dengan mengungkapkan fakta mengenai masyarakat Ternate dan kebudayaannya sebagai langkah awal untuk mengetahui dan mengenal batasan spasial penulisan ini.

\section{A. Asal Usul Masyarakat Ternate}

Kiya raha fato-fato, gapi, duko, tuanane se kiye besi, doka saya rako moi. Ma ronga gam madihutu. Gam madihitu gee maronga Maloku Kiya Raha. Artinya, empat gunung berjejer-jejer, yaitu Ternate, Tidore, Moti, dan Makean sebagai setangkai bunga mawar yang harum baunya. Namanya negeri asal kejadian, itulah namanya Ternate (Abdul Hamid Hasan, 2002).

Pulau Ternate merupakan salah satu wilayah kekuasaan Kesultanan Ternate. Wilayah kesultanan itu kini menjadi bagian dari Kotamadya Ternate yang merupakan kesatuan pemerintahan otonomi dalam Provinsi Maluku Utara. Secara etimologi, kata Ternate berasal dari tiga suku kata, yaitu tara no ate, yang berarti turun ke bawah dan pikat dia. Maksudnya, turun dari tempat yang tinggi (dataran tinggi) untuk mengikat para pendatang supaya mau menetap di wilayah ini (Ternate) (Andi Atjo.2008). Penggunaan nama Ternate dapat ditemukan dalam berbagai sumber sejarah Eropa. De Clercq, mengidentifikasi nama Ternate dalam beberapa pengertian. Pertama, nama sebuah karesidenan. Kedua, nama sebuah kota. Ketiga, nama sebuah kesultanan. Keempat, nama salah satu pulau (F.S.A. de Clercq,1890).

Sejarah asal-usul penduduk Ternate, hingga masih diperdebatkan. Menurut R.Z. Leirissa, penduduk Ternate, termasuk kepulauan Maluku Utara, berasal dari campuran berbagai suku bangsa. Mereka berasal dari ras Malanesia, Proto-Malayu atau Netro-Melayu yang mendiami daerah pedalaman bagian Utara Pulau Halmahera, kemudian menyebar ke Ternate, Tidore, dan pulau-pulau sekitarnya sejak berabad-abad lampau melalui gelombang migrasi yang panjang (R.Z. Leirissa1997). Sejalan dengan itu, menurut L.E. Visser, penduduk tertua kepulauan Maluku Utara mendiami daerah pedalaman Halmahera. Penduduk asli Pulau Halmahera dikenal sebagai Suku Alifuru (manusia awal). Mereka kemudian menyebar dari Pulau Halmahera ke sekitarnya, termasuk Pulau Ternate (L.E. Visser, 1994)

Sejalan dengan itu, menurut Adnan Amal bahwa asal usul penduduk Ternate berasal dari kerajaan Jailolo (Halmahera) yang bermigrasi sekitar tahun 1250 akibat konflik politik antara Raja Jailolo dengan kelompok-kelompok oposisi. Para pelarian tersebut mendirikan pemukiman di dekat puncak Gunung Gamalama yang disebut komunitas Tobona.

Pembentukan komunitas Tobona inilah menandai permulaan terbentuknya organisasi sosial (pra kerajaan) yang di kepalai seorang pemimpin yang disebut momole (kepala kampung/marga). Seiring bertambahnya para imigran maka terbentuklah beberapa pemukiman (komunitas) di Pulau Ternate. Pemukiman baru tersebut yaitu foramadiyahi yang mendiami dataran tinggi. Sampala yang menempati kawasan hutan dan Toboleu yang menempati pesisir pantai Ternate bagian utara. Dalam perkembangannya sekitar 1251 empat kelompok sosial ini mengadakan musyawarah untuk membentuk organisasi kerajaan. Dari musyawah tersebut dipililah Ciko (kepala kampung Sampala) sebagai pemimpin ketiga komunitas tersebut. Pengangkatan Ciko sebagai kolano (raja) pertama Ternate, van der Crab menceritakan bahwa:

Pada suatu hari Momole Guna (kepala suku Tobona), menjelajahi hutan mencari pohon enau untuk menyedap tuaknya. Ia tiba di suatu lintasan jalan dan menemukan sebuah lesung yang terbuat dari emas. Momole Guna mengambilnya dan membawa pulang ke rumah. Lesung emas itu kemudian menjadi tontonan yang aneh bagi warga Tobona. Karena yang ingin melihatnya makin banyak berdatangan, Momole Guna tidak mau menahannya lebih lama lagi dan memutuskan untuk memeberinya kepada Momole Molematitti (kepala suku Foramadiyahi). Mole matiti yang telah menerima menerima lesung anah itu, juga mengalami hal yang sama seperti di alami Momole Guna dari Tobona, karena tidak betah, ia berikan kepada Ciko dari Sampala. Ciko menerima lesung itu 
disertai dengan segala keajaibannya dan dengan demikian ia memperoleh kehormatan menjadi penguasa atas pulau Ternate yang berakhir dengan penobatannya sebagai raja pertama pulau itu dengan gelar kolano (P van der Crab, 1978).

Setelah pengangkatannya sebagai pemimpin, Ciko mengubah gelarnya dari momole menjadi kolano (raja). Demikian pula namanya juga diubah menjadi Mansur Malamo. Ciko inilah yang dipercaya sebagai kolano pertama yang meletakkan dasar bagi hadirnya kerajaan Ternate, sekaligus membentuk struktur kekuasaan dengan kolano sebagai penguasa tertinggi (mengenai stuktur organisasi kerajaan Ternate akan dibahas pada bab selanjutnya). Setelah itu pusat kekuasaan-pun dipindahkan ke tepi pantai yang diberi nama Gamlamo (negeri besar) (Abdul Hamid Hasan, 2002).

Secara kultural, penduduk Kesultanan Ternate tergolong kelompok majemuk atau multikultural. Christiaan Frans van Fraasen mengklasifikasikan penduduk kesultanan ini ke dalam dua kategori. Katagori pertama adalah penduduk pribumi (inheemsche bevolking), yaitu mereka yang berasal kelompok Tubo, Tobana, Tabanga, dan Toboleu yang telah lama dan menetap di Pulau Ternate. Kelompok inilah cikal-bakal terbentuknya Kerajaan Ternate. Kategori kedua adalah penduduk asli bukan orang Ternate (di luar keempat kelompok di atas) ditambah penduduk suku-suku yang berasal dari daerah lain (Christiaan Frans van Fraasen,1987).

Penduduk asli Ternate terbagi empat kelompok kekerabatan yang bersifat otonom (marga), yaitu Marga Soa-Sio, Sangaji, Heku, dan Cim. Salah satu cirinya adalah melestarikan sistem marga. Oleh sebab itu, mereka lebih mudah dikenal dengan nama belakang atau (family name) yang melekat di belakang namanya. Marga inilah yang ikut membedakan mereka dengan etnis lainnya di Ternate. Keempat marga tersebut, menurut Adnan Amal, berasal dari empat kelompok utama pembentukan Kerajaan Ternate, yakni Tubo, Tobana, Tabanga, dan Toboleu yang merupakan penduduk awal Pulau Ternate. Menurut berbagai sumber hingga kini keempat marga utama tersebut, secara turun-temurun memegang jabatan-jabatan politik di lingkungan Kesultanan Ternate (Adnan Amal, 2007).

Sementara penduduk asli bukan orang Ternate, terdiri dari kelompok etnis Tidore, Jailolo, Loloda, Bacan, Makian, dan Sanana. Etnis ini mendiami sebagian daerah Kesultanan Ternate, terutama Ternate Tengah dan Selatan. Mereka dianggap memiliki andil penting dalam proses perkembangan Kesultanan Ternate, sehingga diberikan kedudukan dalam struktur pemerintahan sebagai dewan kerajaan (Bobato Nyagimoi se Tufkange atau dewan delapan belas) dengan gelar masing-masing. Etnis Tidore diberi gelar Sangaji Limatahu. Etnis Jailolo, diberi gelar Sangaji Tomajiko. Etnis Bacan, diberi gelar Kimalaha Labuha, etnis Makian bergelar Sangaji Tokofi, etnis Loloda bergelar Sangaji Malayu-Konora, dan etnis Sula bergelar Salahakan (Anas Dinsie dan Rinto Taib, 2001). Sama halnya dengan keempat marga utama, keberadaan beberapa etnis ini, hingga kini dipegang teguh sebagai landasan utama dalam melakukan rekruitmen politik. Menurut berbagai sumber beberapa etnis tersebut merupakan kelompok inti yang menduduki struktur birokrasi Kesultanan Ternate.

Selain itu, terdapat juga penduduk dari etnis lain dari luar Maluku Utara yang berdiam di wilayah Kesultanan Ternate. Menurut B. Soelarto (1982), terdapat beberapa suku pendatang seperti etnis Melayu, Makassar, Buton, dan Jawa. Kehadiran mereka ke Ternate berkaitan dengan perkembangan perdagangan rempah-rempah yang sangat dibutuhkan dalam jaringan internasional. Sebagai pusat perdagangan rempahrempah di wilayah Nusantara, Ternate memberi kesempatan kepada kelompok suku bangsa tersebut untuk tinggal dan membentuk marga yang diberi nama menurut asal-usul leluhurnya. Misalnya marga Jawa adalah sub suku Ternate yang nenek moyangnya berasal dari Jawa, sehingga memiliki ciri fisik yang serupa dengan orang Jawa (B. Soelarto,1982). Lebih jelasnya dapat dilihat pada tabel berikut. 
Rustam Hasim. 2019. Masyarakat, Kebudayaan, Sejarah dan Pulau Ternate

Tabel 1. Nama-nama Marga yang ada di Ternate

\begin{tabular}{|c|c|c|c|}
\hline No & Nama Kelompok Marga & Nama Kepala Marga & Nama Anak Marga/ Soa \\
\hline \multirow[t]{9}{*}{1} & Sio & Kimalaha & Marsaoli \\
\hline & & & Tomaito \\
\hline & & & Tomagola \\
\hline & & & Tamadi \\
\hline & & & Payahe \\
\hline & & Fanyira & Jiko \\
\hline & & & Jawa \\
\hline & & & Tolangara \\
\hline & & & Tabala \\
\hline \multirow[t]{9}{*}{2} & Sangaji & Sangaji & Tomajiko \\
\hline & & & Malayu \\
\hline & & & Kulaba \\
\hline & & & Malaicim \\
\hline & & & Tobeleu \\
\hline & & & Tafamutu \\
\hline & & & Tafaga \\
\hline & & & Tokofi \\
\hline & & Kimalaha & Labuha \\
\hline \multirow[t]{12}{*}{3} & Heku & Fanyira & Takome \\
\hline & & & Sula \\
\hline & & & Gam cim \\
\hline & & & Tabanga \\
\hline & & & Siko \\
\hline & & & Tafamutu \\
\hline & & & Dodari- isa \\
\hline & & & Mado \\
\hline & & & Togolobe \\
\hline & & & Faudu \\
\hline & & & Tamajiko \\
\hline & & Kimalaha & Tabala \\
\hline \multirow[t]{10}{*}{4} & Cim & Fanyira & Talangam \\
\hline & & & Moyau \\
\hline & & & Tafure \\
\hline & & & Maitara \\
\hline & & & Koloncucu \\
\hline & & & Wucu \\
\hline & & & Tamao \\
\hline & & & Doi \\
\hline & & & Taake \\
\hline & & & Tomahutu \\
\hline
\end{tabular}

Sumber: B. Soelarto, Sekitar Tradisi Ternate. Jakarta: Proyek Pengembangan Media Kebudayaan Departemen Pendidikan Kebudayaan RI, 1982.

Demikian halnya dengan nenek moyang etnis Melayu, Buton, dan Makassar. Walaupun sebagai etnis pendatang, kelompok ini juga diberi kedudukan dalam pemerintahan, misalnya etnis Jawa ditempatkan dalam bobato akhirat (bidang agama) dengan gelar Imam Jawa, begitu pula etnis Makassar, ditempatkan dalam bobato dunia (pemerintahan dunia), dengan diberi gelar sebagai Kapita Makassar. Proses ini 
menarik, karena keberadaan beberapa suku yang mendiami wilayah kerajaan direkrut menjadi anggota kerajaan melalui sistem perwakilan distrik, sebagai landasan legitimasi dan integrasi.

Ternate merupakan daerah kesultanan dan agama Islam menjadi agama resmi yang dianut moyoritas masyarakat. Namun demikian kepercayaan animisme dan dinamisme (agama asal) masih dipraktekan sebagian besar masyarakat Ternate. Menurut berbagai sumber, hingga kini masih terdapat sebagian masyarakat Ternate percaya kepada gunung Gamalama sebagai sumber kekuatan gaib (supranatural) yang dapat dimintai pertolongan untuk memberi keselamatan dan kesejahteraan hidup. Mereka antara lain menjalankan upacara penghormatan dan pemujaan dengan cara mengelilingi gunung Gamalama, yang disebut kololi kiye dan fere kiye. Menurut Abdul Hamid Hasan, kepercayaan-kepercayaan tersebut sedemikian mendarah daging dalam kehidupan masyarakat Ternate. Walau mereka telah memeluk agama Islam mereka masih setia dengan tradisi leluhur mereka. Begitu para sultan, setelah dinobatkan wajib melakukan upacara kololi kiye dan fere kiye (mengelilingi dan menaiki puncak gunung). Hanya saja, upacara itu tidak lagi ditujukan kepada kekuatan gaib gunung Gamalama, melainkan kehadirat Allah SWT (Abdul Hamid Hasan, 2000).

Selain pemujaan terhadap gunung Gamalama, kepercayaan lama lainnya yang dianut sebagian masyarakat Ternate adalah kepercayaan terhadap arca-kayu wonge. Benda tersebut fisik berbentuk lelaki-perempuan sebagai gambaran atau visualisasi nenek moyang mereka. Wonge ditempatkan di luar rumah dalam sebuah rumah-rumahan (fala wonge) yang berisi arca-arca nenek moyang mereka. Tempat itu dilengkapi sesajian berupa nasi kuning, sirih, pinang, tembakau, rokok tuak, dan dupa kemenyan. Wonge dipercaya sebagai penolak bala sekaligus pusat kekuatan gaib yang dapat dimintai pertolongan (Masinambaw E.K.M. (ed.), 1980).

Kepercayaan lama lainnya adalah upacara adat joko kaha (injak tanah). Upacara ini sangat prinsipil dan wajib diselengarakan mulai dari ritus keluarga sampai penobatan sultan.Tujuan ritus ini ialah memberi penghormatan kepada bumi sebagai pusat kekuatan gaib, agar membantu atau memberi keselamatan kepada manusia. Selain itu, sampai kini masih ada pemujaan terhadap roh nenek moyang berupa pemberian sesajian ke tempat keramat kuno (jere). Tempat keramat ini dianggap bisa membawa berkah. Jere sendiri berupa batu yang muncul dengan sendirinya menyerupai makam, sehingga dianggap sebagai makam keramat (B. Soelastro,1978).

\section{B. Mata Pencarian Penduduk}

Tanah dalam wilayah Ternate tergolong subur. Keadaan ini memungkinkan penduduk setempat memenuhi kebutuhan hidup mereka dengan mengolah lahan pertanian. Kombinasi antara kesuburan tanah dan iklim membuat usaha pertanian yang menonjol adalah tanaman cengkeh dan pala. Sisi kesejarahan yang penting dari Ternate adalah peranannya sebagai salah satu pulau penghasil cengkeh di Maluku. Suatu hal yang menjadikan pulau ini ajang kepentingan ekonomi, terutama perebutan rempah-rempah oleh bangsa-bangsa Eropa seperti Portugis, Spanyol, Belanda, dan Inggris (Bahar Andili, 1978).

Faktor utama daya tarik Ternate antar-bangsa itu adalah cengkeh dan pala, sebagaimana dikemukakan Anthony Reid bahwa Pedagang Melayu mengatakan bahwa Tuhan menciptakan Timor untuk kayu cendana, Banda untuk pala, serta Maluku (Ternate) untuk cengkeh, dan barang dagangan ini tidak dikenal di tempat lain di dunia kecuali di tempat itu. Penduduk menanam cengkeh karena mendatangkan hasil dan keuntuntungan berlimpah. Pada mulanya, tanaman tersebut adalah tanaman liar yang tumbuh di hutanhutan yang kemudian ditanam dalam usaha perkebunan (Anthony Reid, 1999).

Meskipun jumlah penduduk Ternate sangat besar dibandingkan prosentase etnis pendatang, namun karena minimnya sumber daya manusia, maka mereka lebih banyak berkerja di sektor non-formal seperti 
pertanian dan perikanan. Selain itu, sebagian penduduk Ternate menjadikan kerajinan rumah tangga sebagai usaha tambahan untuk memenuhi kebutuhan sendiri. Pekerjaan-pekerjaan ini tidak terlalu membutuhkan keahlian khusus. Sementara jabatan-jabatan publik seperti, guru, polisi, tenaga kesehatan, maupun birokrasi, lebih banyak dikuasai etnis pendatang (Sutrisno Kutoyo,1978).

Tabel 2. Mata Pencarian Penduduk Ternate

\begin{tabular}{lll}
\hline No & Mata Pencarian & Presentase \\
\hline 1 & Pegawai negeri/swasta & $6,5 \%$ \\
2 & Perikanan/nelayan & $21,2 \%$ \\
3 & Pertanian & $44 \%$ \\
4 & Perdagangan & $11,9 \%$ \\
5 & Jasa/buruh & $10,4 \%$ \\
\hline
\end{tabular}

Jumlah penduduk Pulau Ternate berdasarkan sensus tahun 1961 sebanyak 24.287 orang (lihat tabel 3). Perkembangan jumlah penduduk Ternate dari tahun ke tahun mengalami peningkatan pesat. Faktor utama daya tarik Kota Ternate adalah sebagai pusat pemerintahan, pendidikan, dan perdagangan.Terbukanya kesempatan berusaha mendorong para pendatang dari berbagai daerah di Indonesia untuk berdomisili di Ternate. Dalam hal ini secara garis besar dapat disimpulkan terdapat tiga penggolongan penduduk yaitu penduduk asli Ternate, penduduk Indonesia pendatang, dan golongan penduduk orang asing.

Tabel 3 Jumlah Penduduk Desa Kotapraja Ternate Menurut Perincian Kecamatan Pada Tahun 1961

\begin{tabular}{llccc}
\hline Kecamatan & Desa & Laki- laki & Perempuan & Jumlah \\
\hline & 1. Wijk LTR. A & 2.689 & 2.560 & 5.249 \\
& 2. Wijk LTR. B & 5.636 & 5.315 & 10.951 \\
& 3. Wijk LTR. C & 1.700 & 1.555 & 3.255 \\
& 4. Wijk LTR.D & 1.463 & 1.346 & 2.809 \\
& 5. Wijk LTR.E & 710 & 690 & 1.400 \\
Jumlah & 6. Wijk LTR.F & 326 & 297 & 623 \\
Jumlah Seluruh & Desa = 6 & 12.524 & 11.763 & 24.287 \\
Kotapraja & Kecamatan $=1$ & 12.524 & 11.763 & 24.287 \\
\hline
\end{tabular}

Sumber: Sensus Penduduk 1961 Penduduk Desa Sulawesi dan Maluku, Pusat Penelitian dan Studi Kependudukan Universitas Gadjah Mada Yogyakarta dan Biro Pusat Statistik, 1980, hlm. 230.

\section{Pendidikan}

Perkembangan pendidikan di Ternate pasca-kemerdekaan Republik Indonesia, belum mengalami kemajuan. Masih banyak penduduknya yang buta huruf. Perkembangan pendidikan di Ternate baru dimulai sejak tahun 1950 atau saat bubarnya Negara Indonesia Timur (NIT). Hal ini ditandai dengan disusunnya suatu organisasi pendidikan oleh Departemen Pendidikan dan Kebudayaan No. 4 tahun 1950 tentang dasar-dasar pendidikan dan pengajaran di sekolah (R.Z. Leirissa, 1975).

Usaha-usaha peningkatan pendidikan dapat berjalan dengan baik memasuki tahun 1951 dengan disusunnya organisasi pendidikan oleh Departemen Pendidikan dan Kebudayaan yang bertanggungjawab di bidang pendidikan dan kebudayaan Maluku. Organisasi pendidikan baru ini secara sentral mengatur semua pendidikan di seluruh pelosok Maluku dan Ambon sebagai pusat kegiatan. Perwakilan Departemen Pendidikan dan Kebudayaan itu menyelenggarakan urusan-urusan pendidikan, mulai dari pendidikan pra 
sekolah, pendidikan dasar, pendidikan menengah baik umum maupun kejuruan, pendidikan masyarakat seperti pemberantasan buta huruf, kegiatan-kegiatan umum seperti olahraga, pendidikan kebudayaan, kesenian, serta pengadaan tenaga pengajar (Sem Touwe dan Rina Pusparani, 2013). Jumlah dan gambaran aktivitas sekolah di Maluku periode tahun 1950-an dapat dilihat pada Tabel 4.

Tabel 4. Jumlah Sekolah, Guru, dan Murid di Maluku pada Tahun 1950

\begin{tabular}{clcc}
\hline No & Nama Sekolah & Jumlah Sekolah & Jumlah Murid \\
\hline $\mathbf{1}$ & Sekolah Rendah & 398 & 46700 \\
$\mathbf{2}$ & Sekolah Rendah Umum & 67 & 8600 \\
$\mathbf{3}$ & Sekolah Pendidikan Guru & 46 & 1475 \\
$\mathbf{4}$ & Sekolah Normal & 14 & 1120 \\
$\mathbf{5}$ & Mulo & 6 & 1750 \\
$\mathbf{6}$ & Sekolah Menegah & 19 & 1980 \\
$\mathbf{7}$ & HBS/AMS & 1 & 300 \\
$\mathbf{8}$ & Sekolah Pangreh Praja yang Pindah dalam & 1 & 60 \\
$\mathbf{9}$ & Pendidikan Menengah & 4 & 100 \\
$\mathbf{1 0}$ & Sekolah Teknik Rendah & 10 & 780 \\
$\mathbf{1 1}$ & Sekolah Kepandian Gadis Tingkat Pertama & - & - \\
& Jumlah & 3966 & 62865 \\
\hline
\end{tabular}

Sumber: Algemeen Verslag van Nijverheidsonderewijs een nijverheidssholen 1948, dalam Arsip Tanah Toraja 489/48 Anriwil Sulsel

Selain sekolah-sekolah yang dibangun oleh pemerintah, terdapat pula yayasan-yayasan pendidikan seperti yayasan pendidikan gereja-gereja Protestan, Roma Katolik, dan organisasi-organisasi Islam seperti Muhamadiyah dan ABRI. Pada perkembangan selanjutnya, dibangun juga beberapa perguruan tinggi seperti Universitas Pattimura tahun 1956, Universitas Khairun Ternate 1964, Sekolah Tinggi Agama Islam Negeri Ternate 1966, Universitas Muhammadiyah 1999, Sekolah Tinggi Ilmu Pendidikan (STIKIP) Kie Raha tahun 2001, AIKOM Ternate, dan Akademi Keperawatan (APPER) Ternate.

Pendidikan formal ini di kemudian hari berfungsi sebagai katalisator bagi terwujudnya dua jenis elite, yakni elite tradisional (istana) dan elite modern (birokrat dan intelektual). Kedua elite tersebut berasal dari tradisi pendidikan yang sama, tetapi berada dalam lingkungan politik dan hierarki sosial berbeda. Elite pertama lebih didukung oleh legitimasi budaya, sedangkan elite kedua berkat keunggulan merek di bidang ilmu pengetahuan. Pada aspek ini, kemajuan pendidikan memberi peluang besar bagi terjadinya perubahan sosial, khususnya mobilitas sosial. Sistem pengangkatan pegawai tidak lagi hanya berdasarkan status dan keturunan, tetapi juga berdasarkan jenjang pendidikan.

\section{Budaya Politik}

Masyarakat Ternate telah terorganisasi secara geneologis ke dalam kelompok-kelompok sosial dengan ciri khas masing-masing. Kesatuan kelompok sosial tersebut disebut soa (marga) oleh masyarakat Ternate. Tiap-tiap kampung terdiri dari beberapa soa dan setiap soa dikepalai oleh seorang kimalaha atau fanyira (kepala kampung). Penggunaan sebutan-sebutan tersebut tergantung pada jauh dekat hubungannya dengan pusat kekuasaan. Pengangkatan kepala-kepala soa tersebut selalu di dasarkan pada faktor keturunan (Abdul Hamid Hasan, 2000).

Masyarakat Ternate pada umumnya dikenal sebagai masyarakat yang sangat ketat mempertahankan aturan pelapisan sosial. Bagi mereka, mempertahankan pelapisan sosial dipandang sebagai satu syarat memperjaya 
dan menjaga kehormatan. Artinya, perbedaan peranan-peranan dipandang sebagai norma yang patut dipelihara, diikuti, dan dijalankan dalam kehidupan mereka. Hal penting yang harus diperhatikan dalam hubungannya dengan anggapan ini adalah kedudukan kelompok bangsawan sebagai kelompok yang dapat dan boleh menjadi pemimpin (Ch. F. van Fraasen, 1983).

Masyarakat Ternate, seperti halnya masyarakat di kerajaan Jawa (Yogyakarta dan Surakarta) yang mengenal pelapisan sosial yang tersusun secara hirarki. Meski penggolongan masyarakat tidak setajam pembagian kasta-kasta dalam struktur sosial feodal, namun ada penggolongan yang bertolak atas dasar keturunan (geneologis). Tingkatan tertinggi adalah golongan kolano (sultan) yang terdiri dari sultan dan keluarganya sampai tiga lapis atau tingkatan turunannya. Dalam struktur Politik Kesultanan Ternate, sultan adalah titik pusat kekuasaan. Sebagai puncak hierarki, sultan memegang kekuasaan yang besar. Hal itu tercermin dari kepemilikannya terhadap benda-benda pusaka, gelar, ataupun silsilah geonologis (Hasyim, 2017).

Tingkatan pertama adalah anak-anak sultan bergelar "kaicil" untuk putra dan boki atau "nyaicil" untuk putri. Jika anak-anak itu berada pada jenjang ketiga dari sultan yang berkuasa, mereka bergelar "jou ma datu". Sementara jenjang keempat bergelar "jou mamuse". Selanjutnya, tingkatan kedua (danu) atau golongan bangsawan yang masih memiliki hubungan darah dengan keluarga sultan. Seperti cucu sultan dan anak-anak yang dilahirkan dari putri sultan dengan orang dari lingkungan istana. Termasuk juga kaum bangsawan yang diangkat menjadi pejabat birokrasi kerajaan dan golongan agama. Tingkatan ketiga adalah rakyat biasa atau disebut "bala kusu se kano-kano" (M. Shaleh A. Putuhena, 1983).

Kelompok bangsawan (elite) merupakan lapisan teratas yang mempunyai kedudukan politik, sosial, dan ekonomi yang lebih tinggi. Mereka inilah yang mendominasi kepemimpinan dalam masyarakat. Puncak hierarki ditempati sultan yang memiliki otoritas tradisional yang telah diterimannya sebagai hak turuntemurun. Hal itu tercermin pada nama atau gelar yang disandangnya. Di bawah sultan terdapat golongan bangsawan, yang dalam Kesultanan Ternate dibedakan atas bangsawan pusat dan bangsawan daerah.

Bangsawan pusat adalah kelompok bangsawan yang berasal dari marga Soa-Sio, (Soa Marasaoli, Limatahu, Tomagola, dan Tomaito). Mereka merupakan inti dari penduduk Ternate dan merupakan marga yang dipilih untuk menduduki jabatan bobato madopolo (dewan menteri) dan bobato nyagimoi se tufkange (lembaga legislatif). Dengan fungsi politik yang melekat kepadanya (mengangkat dan memberhentikan) seorang sultan, maka sejak zaman dahulu hingga sekarang soa ini mempunyai kedudukan terhormat setelah kerabat sultan. Kelompok bangsawan ini dipandang mempunyai jenjang kebangsawanan lebih tinggi dari jenjang kebangsawanan daerah.

Sementara bangsawanan daerah adalah kelompok bangsawan keturunan marga Sangaji dan Salahakan. Mereka umumnya menjadi utusan sultan (kepala distrik) untuk mengatur dan menjalankan pemerintahan serta mengurus kepentingan sultan di daerah-daerah yang jauh dari pusat kerajaan atau sebarang pulau. Umumnya penempatan dan pengangkatan seorang Sangaji (kepala distrik) dan Salahakan (utusan sultan), bergantung pada kemurnian darah kebangsawanannya. Hal ini dipandang sebagai suatu ketentuan karena dalam struktur pemerintahan Kesultanan Ternate, bangsawan yang berasal dari marga Sangaji tidak dapat dan tidak boleh melaksanakan kekuasaan atas golongan yang lebih tinggi (marga Soa-sio). Aturan dan ketentuan ini menuntut pengaturan jenjang kebangsawanan berkaitan sejajar dengan kepangkatan kekuasaan.

Dalam usaha untuk memperluas pengaruh, mempertinggi kewibawaan, mempertahankan kekuasaan, kaum bangsawan senantiasa mengandalkan selain kekuasaan dan kepintaran perluasan jaringan hubungan kekeluargaan. Suatu hal yang oleh Chabot disebut perkawinan politik antar-bangsawan. Menurut Edward L. 


\section{GeoCivic Jurnal}

Vol 2, Nomor 2, Oktober 2019

Poelingggomang, perkawinan antar-bangsawan menunjukkan dua kecenderungan. Pertama, usaha untuk menjalin hubungan kekeluargaan yang lebih erat. Kedua, usaha ke arah hubungan dengan anggota kelompok lain dengan maksud mencapai hubungan yang menguntungkan (Edward L. Poelinggomang, 2004).

Dasar hubungan perkawinan antar-bangsawan ini juga menunjukan bahwa perkawinan merupakan alat untuk memperluas jaringan kekerabatan. Semakin luas jaringan kekeluargaan, semakin luas pula pengaruh kelompok itu. Hal itu akan mempertinggi kewibawaan pemimpin kelompok dalam memperkuat kedudukan kekuasaannya. Dengan kata lain, kecenderungan memperluas pengaruh, kewibawaan, dan kekuasaan lewat hubungan perkawinan, menunjukan bahwa masalah kekuasaan politik tidak dapat dipisahkan dari kekerabatan.

Pembagian atau pelapisan sosial dalam masyarakat Kesultanan Ternate berdampak pada penyematan gelar atau titel yang dipergunakan sebagai ciri utama untuk membedakan mereka satu sama lain. Misalnya, gelar Soa-Sio dan Sangaji hanya diperuntukkan bagi bangsawan yang menduduki Bobato Madopola (dewan kerajaan). Sementara gelar heku dan cim diberikan kepada petugas-petugas yang mengurusi keamanan kerajaan.Gelar pada dasarnya merupakan perwujudan dari garis keturunan yang bersandar pada individu yang berada dalam kerangka geneologis yang sama dari pihak laki-laki (patrilineal) dan terkadang terkait secara unilinear ke satu sumber (Christiaan Frans van Fraasen, 1978).

Pada golongan bagsawan, terdapat pula perbedaan menurut tingkatannya sesuai dengan jasa dan hubungan kekerabatan seseorang dengan sultan. Hingga kini, dalam kehidupan adat masyarakat Ternate, golongan kolano (sultan) dan golongan dano (bangsawan) merupakan kelompok elite. Demikian pula pengelompokan soa, masih diakui sebagai lembaga adat dalam kehidupan sehari-hari. Bangsawan masih merupakan kelompok atas dan mempunyai kekuasaan yang sangat besar. Sementara bentuk hubungan bangsawan dengan penduduk berupa hubungan tambal-balik antara patron dan klien. Kaum bangsawan berkewajiban memberikan perlindungan kepada penduduk dan sebaliknya, penduduk memberikan imbalan berupa barang, jasa, dan tenaga kepada kaum bangsawan (Hasmawati \& Hasim, 2017).

Pelapisan sosial di atas memberi pengaruh pada sistem kepemimpinan politik, terutama di tingkat pusat kerajaan (sultan). Rakyat yang memandang penting adanya keluarga inti (kekerabatan patrilinial maupun bilateral) memiliki ketaatan mutlak yang didasarkan kepada tatanan budaya politik (Jou kasa ngom ka ge) yang artinya, di mana sultan, di situlah kami. Hal itu menempatkan sultan sebagai wakil Tuhan di muka bumi. Penolakan terhadap keputusan sultan (Iddin Kolano) akan mendatangkan malapetaka. Hal itu pula diyakini oleh para bangsawan, sehingga mereka tidak perlu mengontrol rakyatnya. Ada keyakinan bahwa setiap kesalahan yang dibuat oleh rakyatnya, akan dilaporkan karena mereka takut akibatnya jika tidak segera diselesaikan. Keyakinan akan adanya hubungan erat antara Jou (sultan) dan bala (rakyat), membuat tatanan kultural yang berlaku senantiasa ditaati dan dipertahankan karena dipandang memiliki kekuatan magis dengan melindungi tatanan sosial dan politik yang ada (Radjiloen L., 1982).

Bagi masyarakat Ternate, hubungan antara sultan dan bawahan berlaku hubungan patron-clien (Jou se ngofa ngare) atau menurut istilah Jawa disebut hubungan gusti-kawula. Meskipun demikian, jika dilihat dari hierarkinya, maka raja mempunyai kedudukan lebih tinggi dari pada rakyat. Dalam hubungan ini, sultan mendapat kedudukan khusus dalam masyarakat sebagai kelompok tersendiri yang dapat melaksanakan kekuasaan atas rakyat dan menempati strata bangsawan yang tinggi. Mereka ditempatkan sebagai tokoh yang dapat menghubungkan dunia atas dan dunia bawah yang kemudian menjadi pemegang kendali kehidupan pemerintahan dan dianggap memiliki kekuatan suprtanatural yang dapat menciptakan ketertiban dan kesejahtraan rakyat (Suhartono, 1995). Oleh karena itu, segala titah dan perintah dipandang sebagai 
hukum yang harus ditaati suluruh rakyat. Pelanggaran atau pengingkaran atas titah dan perintah sultan dipandang sebagai sikap penghinaan atas kedudukannya dan akan berdampak malapetaka.

Gambaran stratifikasi sosial itu kini telah berubah. Telah terjadi perubahan sejalan dengan proses moderenisasi. Pembukaan sekolah-sekolah pada perkembangan selanjutnya melahirkan kelas baru dalam masyarakat. Sehubungan dengan itu, para rakyat dapat menyekolahkan anak-anak mereka agar dapat masuk dalam jajaran birokrasi. Jika dahulu sultan dan kerabatnya yang mendominasi kegiatan pemerintahan, kini telah terbuka peluang kepada rakyat melalui pendidikan dan kemampuan dalam bidangnya menjadi prasyarat utama untuk masuk dalam jajaran birokrasi (Muhammad, 2004).

Setelah proklamsi kemerdekaan, kedudukan kaum bangsawan mengalami transisi. Pada satu sisi, terdapat elite tradisional yang tetap mempertahankan statusquo dan memandang setiap perubahan sebagai ancaman bagi mereka. Sementara di pihak lain, terdapat golongan elite baru yang yang memegang kepemimpinan dan menghendaki perubahan. Sementara di saat yang sama, terjadi perubahan persyaratan untuk masuk dalam lingkungan birokrasi dan terbuka peluang luas bagi penduduk untuk memperoleh pendidikan yang tinggi (Sartono Kartodirdjo, 1981).

Perubahan-perubahan di atas, dalam perkembangannya kemudian, mempengaruhi tatanan budaya masyarakat Ternate. Konvensi yang sebelumnya berlaku dalam masa kerajaan yang menekankan bahwa merekalah yang berada pada strata yang lebih tinggi yang boleh melaksanakan kekuasaan atas kelompok berstrata lebih rendah kini telah pudar. Tidak dapat disangkal bahwa dampak dari birokratisasi pemerintahan dan penyelengaraan pendidikan telah melapangkan terjadinya mobilisasi sosial. Hal itu berpengaruh pula terhadap pola hubungan antara bangsawan dengan rakyat. Meski dalam kehidupan kekinian, keberadaan kaum bangsawan masih dapat terindetifikasi.

Dalam perkembangannya, tidak jarang tampil seorang pejabat birokrasi dari kalangan rakyat biasa dan menjalankan kekuasaan terhadap bawahannya yang berdarah bangsawan. Menurut Suhartono W. Pranoto, proses modernisasi telah mengubah masyarakat tradisional dan menciptakan pergeseran peran serta fungsi dari lembaga-lembaga lama ke baru. Sistem pendidikan yang mengarah ke birokrasi modern memungkinkan terjadinya mobilitas sosial. Golongan terpelajar yang secara perlahan mendapat kesempatan untuk menduduki posisi yang sama dengan golongan aristokrat, menyebabkan terjadinya mobilitas sosial (Suhartono W. Pranoto, 2001). Hal ini tampak pada pergeseran sistem sosial, strata ekonomi, posisi politik, sampai gaya hidup. Sementara para bangsawan, masih tetap bertahan dalam status tradisionalnya. Hal itu membuat jabatan-jabatan dalam struktur Kesultanan Ternate masih didominasi golongan bangsawan secara turun-temurun.

\section{Penutup}

Penduduk Ternate dewasa ini terdiri atas berbagai suku bangsa Indonesia yang berimigrasi ke daerah ini sejak masa Kolonial. Bahkan bila dikaji lebih jauh ke belakang sejak masa Emporium dan masa Emperium, telah banyak suku bangsa bahkan ras-ras dari berbagai negara dan benua telah datang ke daerah ini. Pertemuan antara ras dan suku bangsa ini, kemungkinan besar telah terjadi pencampuran sehingga melahirkan keturunan-keturunan yang baru dengan berbagai polah tingkah budayanya. Kota Ternate tumbuh sebagai pusat kegiatan ekonomi dan perdagangan meletakkan hubugan kominakasi jauh keluar batas-batas Nusantara. Sebagai akibat hubungan-hubungan itu terjadi konvergensi gerakan barang dan manusia ke kota-kota tersebut. Dengan demikian tercita kondisi sosial budaya bahkan sosiolonguistik yang memungkinkan berkembangnya segala unsur kebudayaan.

Sebelum agama Islam diterima oleh penduduk Pulau Ternate, orang Ternate telah terbagi atas empat kelompok kekerabatan. Keempatnya adalah Marga Tubo, Marga Tobana, Marga Tabanga, dan Marga 
Toboleu. Masyarakat Ternate terbagi dalam susunan sosial yang tradisioal. Meskipun penggolongan masyarakat tidak setajam pembagian kasta-kasta dalam struktur sosial feodal, namun ada penggolongan yang bertolak atas dasar keturunan. Dengan kata lain pembagian masyarakat Ternate tidak bersifat fungsional. Disamping pembagian struktur kehidupan sosial seperti tersebut diatas, masi ada lagi pembagian kelompok kekerabatan dalam soa atau marga, yang merupakan kelompok berdasarkan kekerabatan murni yang membagi seluruh masyarakat Ternate atas 41 kelompok kekerabatan.

Bahasa Ternate merupakan bahasa induk dari berbagai bahasa daerah di Maluku Utara. Bahkan pengaruhnya sampai di pulau Mindano, kepulawan Sula, Sabah di Kalimantan Utara, Sulawesi Utara, sepanjang Sulawesi Tengah-Selatan, pulau Banggai, pulau Waigeo, Pulau Morotai. Adapun bahasa-bahasa daerah di Ternate, Halmahera, Tidore disebut "Kie se gam". Berbagai bahasa daerah di Maluku Utara masi tetap dipergunakan sebagai bahasa lokal. Ada yang berpendapat bahwa bahasa Terante termasuk rumpun bahasa Austronesia, berdasarkan kesamaan dalam segi tata bahasa (pronauncation dan vocabulary).

\section{DAFTAR PUSTAKA}

Andaya, Leonard Y. (1993). The Wold of Maluku Eastem lndonesia in the Early Moden Period, Honolulu: University of Hawai Press

A.M. Beretta. 1917. Halmahera and Morotai, Batavia: Javasche Boekhandel

A.B. Lapian, dalam pengantar Memorie van Overgaua J.H. Tobias (1857). (1980). Memorie van Overgave C. Bosscher Residen Temate (1859), Jakarta:ANRI

Clercq,F.S.A. (1820). Bijdngen tot de Kennmis der Residentie Temate. Leiden: Brill.

Crab, (1862). De Moluksche Eiland, Rerse van Z.E. den Gouvemeurt Genenal Ch.f. Fahud Door den Molukschen Arcipel. Batavia: Lange.

Grap, P van der. (1978). Geschiedenis van Ternate, in Teranataansche en Maleische Tekst, Beschreven Dor den Ternatean Naidah, Met Vertaling en Aante keningen Door P. A. van der Cerap ". dalam BK1, jilid 26. No 2

Cribb Robert, ed., (1994). The Late Colonial State in lndonesia: Politikal en Ekonomi Fondations of the Netherlands Indies 18801942, Leiden: KITLV Press.

Djoko Suryo, et. al., (2001). Agama dan Perubahan Sosial Studi Tentang Hubungan Antar lslam, Masyarakat dan Struktur Sosial Politik, Yogyakarta UGM LKPSM.

Hasmawati, H., \& Hasim, R. (2017). KEDUDUKAN ELITE KESULTANAN DALAM MASYARAKAT TERNATE. JURNAL ILMU BUDAYA, 5(2 Desember).

Hasyim, R. (2017). Dari Mitos Tujuh Putri hingga Legitimasi Agama: Sumber Kekuasaan Sultan Ternate. SASDAYA: Gadjah Mada Journal of Humanities, 1(2), 144-163.

Muhammad, S. (2004). Kesultanan Ternate: sejarah sosial, ekonomi, dan politik. Ombak.

E.K. M. Masinambaw. (1980). Halmahera dan Raja Ampat Konsep dan Strategi Penelitian, Jakarta: LEKNAS-LIPI.

Edward L. Poelinggomang. (1991). Proteksi dan Perdagangan Bebas: Kajian Tentang Perdagangan Makasar Pada Abad ke-19”, Amsterdam: Academisch Proefschrieft de Vrije Universiteit te Amsterdam.

Fraassen, F van. (1987). Ternate de Molukken en de Indonesische Archipel. Van soa organisatie en Viedeling: Een Studie van Traditionele Samenleeving en Cuoltuur in Indonesie". Disertasi Leiden.

Garraghan, J. Gilbeft. (1957). A. Guide to Histoical Method, New York: Fordham University Press.

Hanna Willard A. (1983). Kepulauan Banda Kolonialisme dan Akibatnya di Kepulauan Pala. Jakarta: Gramedia. 
Rustam Hasim. 2019. Masyarakat, Kebudayaan, Sejarah dan Pulau Ternate

I Gde Parimartha. (2002). Perdagangan dan Politik di Nusa Tenggara 18161915, Jakarta: Penebit Djambatan.

Jusuf Abdulrahman, et al., (2001). Temate Bandar Jalur Sutra, Jakarta:LlTS.

Kotoppo, L. (1984). Nuku Perjuangan Kemerdekaan di Maluku Utara, Jakartra: Sinar Harapan.

Kontowijoyo, (2001). Pengantar llmu Sejarah, Yogyakarta: Yayasan Benteng Wijaya.

Lindblad, J. Thomas et al., (1998). Sejarah Ekonomi Modern Indonesia (Ed.), Jakarta: Pustaka LP3ES.

Rustam Hasim, "Dari Mitos Tujuh Putri hingga legitimasi Agama; Sumber kekuasaan Sultan Ternate,”

R.Z. Leirissa, et. al., (1999). Temate Sebagai Bandar Jalur Sutra, Jakarta: Proyek Inventarisasi dan Dokumentasi Sejarah Nasional Diroktorat Sejarah dan Nilai Nasional, Depdikbud, Rl. 